\title{
NEUROLOGIC COMPLICATIONS AFTER HEART TRANSPLANTATION
}

\author{
Suzana M.F. Malheiros', Dirceu R. Almeida², Ayrton R. Massaro', Adauto Castelo, \\ Rosiane V.Z. Diniz², João N. Branco ${ }^{4}$, Antonio C. Carvalho², Alberto A. Gabbai ${ }^{1}$
}

\begin{abstract}
Objective: Neurologic complications are known as important cause of morbidity and mortality in orthotopic heart transplantation. Our aim was to identify the frequency and outcome of neurologic complications after heart transplantation in a prospective observational study. Method: From September 93 to September 99, as part of our routine heart transplantation protocol all patients with end-stage cardiac failure were evaluated by the same neurologist before and at the time of any neurologic event (symptom or complaint) after transplantation. Results: Out of 120 candidates evaluated, 62 were successfully transplanted (53 male; median age 45.5 years, median follow-up 26.8 months). Fifteen patients (24\%) had ischemic, 22 (35\%) idiopathic, 24 (39\%) Chagas' disease and 1 (2\%) had congenital cardiomyopathy. Neurologic complications occurred in 19 patients (31\%): tremor, severe headache, transient encephalopathy and seizures related to drug toxicity or metabolic changes in 13; peripheral neuropathy in 4; and spinal cord compression in two (metastatic prostate cancer and epidural abscess). No symptomatic postoperative stroke was observed. Conclusions: Although frequent, neurologic complications were seldom related to persistent neurologic disability or death. Most of the complications resulted from immunosuppression, however, CNS infection was rare. The absence of symptomatic stroke in our series may be related to the lower frequency of ischemic cardiomyopathy.
\end{abstract}

KEY WORDS: heart transplantation, postoperative complications, Chagas' disease, cardiomyopathy, stroke.

\section{Complicações neurológicas em transplantes cardíacos}

RESUMO - Objetivo: Complicações neurológicas são frequentemente descritas como causa de morbidade e mortalidade em transplantes cardíacos. Nosso objetivo foi avaliar a frequência de complicações neurológicas em pacientes submetidos a transplantes cardíacos, bem como sua evolução, através de um estudo prospectivo observacional. Método: Todos os candidatos a transplantes cardíacos foram avaliados pelo mesmo neurologista, como parte do protocolo de rotina de avaliação pré-transplante no período de 9/93 a 9/99. Após a cirurgia, os pacientes foram reavaliados sempre que houvesse qualquer sintoma ou queixa neurológica. Resultados: Entre 120 pacientes avaliados no período pré-operatório, 62 foram transplantados (53 sexo masculino; idade mediana de 45.5 anos; tempo de seguimento mediano 26.8 meses). A etiologia da miocardiopatia foi isquêmica em 15 pacientes (24\%), idiopática em 22 (35\%), chagásica em 24 (39\%) e congênita em 1 (2\%). Complicações neurológicas ocorreram em 19 pacientes (31\%): tremor, cefaléia intensa, encefalopatia transitória ou crises relacionados com toxicidade medicamentosa ou alterações metabólicas em 13; neuropatia periférica em 4; compressão medular em 2 (metástase epidural de carcinoma de próstata e abscesso epidural). Nenhum paciente apresentou acidente vascular cerebral (AVC) sintomático no período pós-operatório. Conclusões: Apesar de frequentes, as complicações neurológicas raramente provocaram seqüelas permanentes ou óbito. A maior parte das complicações foi relacionada com imunossupressão, entretanto, infecções foram raras. A ausência de pacientes com AVC sintomático pode estar associada com a baixa frequência de miocardiopatia isquêmica na presente série.

PALAVRAS-CHAVE: transplante cardíaco, complicações pós-operatórias, doença de Chagas, miocardiopatia, transtornos cerebrovasculares.

Neurologic complications are known to be an important cause of morbidity and mortality in otherwise successful heart transplantation. Those complications have been described in up to $94 \%$ of pati- ents, but some series are based on autopsy findings and therefore may be potentially biased ${ }^{1-4}$. The most common neuropathologic findings described in these series are cerebrovascular events and central nervous Department of Neurology', Cardiology² ${ }^{2}$ Infectious Diseases ${ }^{3}$ and Cardiovascular Surgery ${ }^{4}$, Universidade Federal de São Paulo, São Paulo
SP, Brazil (EPM/UNIFESP).

Received 8 August 2001, received in final form 23 October 2001. Accepted 30 October 2001.

Dra. Suzana M.F. Malheiros - Department of Neurology EPM/UNIFESP - Rua Botucatu 740 - 04023-900 São Paulo SP - Brazil. FAX: 55113023 3051. E-mail: suzana@sun-nepi.epm.br 
system (CNS) opportunistic infections. However, most of the autopsy studies were published in the 1970s and 80 s and, since then, many improvements in surgical techniques as well as immunosuppression have led to increasing survival rates and probably also to changes in the nature, frequency and outcome of the complications observed. Clinical studies have described far fewer neurologic complications in those patients; however, being retrospective, based on chart reviews and autopsy findings, they may have underestimated the frequency of the complications reported ${ }^{5-10}$.

There are some recent clinical retrospective series in the pediatric population ${ }^{11-13}$, that are not comparable, considering that children have distinct cardiomyopathies and risk factors.

As far as we know, the only prospective study in adult patients addressed exclusively the cerebrovascular complications of heart transplantation ${ }^{14}$.

The aim of our study was to identify the frequency and outcome of neurologic complications in a prospective observational study in our University Hospital.

\section{METHODS}

From September 1993 to September 1999, as part of our routine heart transplant protocol approved by the local ethics committee, all patients over 15 years of age with end-stage cardiac failure were evaluated by the same neurologist, preoperatively and, after the operation, at the time of any neurological event as detected by the transplant team. Patients were subjected to a detailed preoperative neurologic examination and, after the operation all patients with neurologic symptom or complaint were reexamined. Whenever indicated, cranial CT and/or MRI, CSF examination and electrophysiologic studies were performed.

Primary cardiac diseases included ischemic, idiopathic and congenital cardiomyopathy and also Chagas' disease, a very prevalent disease in Brazil ${ }^{15}$.

\section{Transplant protocol}

Exclusion criteria included present infection, neoplasm, renal, hepatic or pulmonary failure, pulmonary hypertension and dementia or psychiatric illness.

Orthotopic heart transplantations were performed under cardiopulmonary bypass with moderate hypothermia $\left(28^{\circ} \mathrm{C}\right)$, non-pulsatile flow, membrane oxygenators, and alpha-stat management. Prophylactic antibiotic (cefazolin) was used in all patients.

The immunosuppressive protocol consisted of: 1) methylprednisolone $500 \mathrm{mg}$ before the end of bypass and $700 \mathrm{mg}$ to $1 \mathrm{~g}$ IV from the first to the third postoperative day, followed by oral prednisone 0.8 to $1.0 \mathrm{mg} / \mathrm{kg} / \mathrm{day}$, progressively reduced to 0.15 to $0.2 \mathrm{mg} / \mathrm{kg} / \mathrm{day} ; 2$ ) cy- closporine 5 to $6 \mathrm{mg} / \mathrm{kg} /$ day beginning on the fourth postoperative day, with doses adjusted to maintain blood levels of $200 \mu \mathrm{g} / \mathrm{dl}$; 3) azathioprine $4 \mathrm{mg} / \mathrm{kg} /$ day immediately before the operation and 2.0 to $2.5 \mathrm{mg} / \mathrm{kg} / \mathrm{day}$ as of the first postoperative day.

Endomyocardial biopsy was performed weekly in the first postoperative month, twice in the second month, monthly until the sixth month, and whenever necessary thereafter. In Chagas' patients biopsies were also stained with Giemsa and immunohistochemistry to $T$. cruzi.

Only greater than grade II (ISHLT) rejection ${ }^{16}$ episodes were treated with boluses of IV methylprednisolone followed by oral prednisone.

In Chagas' patients prednisone was withdrawn in the third postoperative month in order to minimize the risk of reactivation due to immunosuppression and none of them received prophylaxis to $T$. cruzi infection reactivation. Diagnosis of clinical Chagas' disease reactivation was based on detection of $T$. cruzi in blood samples (xenodiagnosis and culture) and tissue biopsies. Whenever confirmed, all reactivations were treated with allopurinol 600 to $900 \mathrm{mg} /$ $\mathrm{kg} /$ day during 60 days $^{17,18}$.

\section{Statistical analysis}

Demographics and risk factors for cerebrovascular diseases were compared for patients with and without neurologic complications using Mann-Whitney $U$ test for continuous variables and Fisher's exact test for categorical and dichotomous variables. For all tests, statistical significance was accepted at $p<0.05$.

\section{RESULTS}

Out of 120 candidates evaluated, 62 were successfully transplanted. There were 53 men $(85 \%)$ with a median age of 45.5 years (ranging from 16 to 68 years). The median follow-up was 26.8 months (ranging from 0.3 to $70.6+$ months).

The prevailing etiology of cardiomyopathy was Chagas' disease in 24 patients (39\%); 22 patients (35\%) had idiopathic cardiomyopathy, 15 (24\%) had ischemic cardiomyopathy, and only one ( $2 \%$ ) patient had congenital cardiomyopathy (transposition of great arteries).

Table 1 shows demographic features and risk factors for cerebrovascular diseases in Chagas', idiopathic (including in this group the only patient with congenital cardiomyopathy) and ischemic patients.

Preoperative evaluation revealed three patients (2 ischemic, 1 idiopathic) with previous strokes with mild motor deficits, one (Chagas') with previous TIA and two diabetic patients ( 1 ischemic and 1 idiopathic) with mild peripheral neuropathy.

Neurologic complications occurred in 19 patients (31\%) (Table 2). Transient encephalopathy and/or seizures were observed in 11 patients ( 3 Chagas'; 5 id- 
Table 1. Demographics and risk factors for cerebrovascular disease in heart transplant recipients.

\begin{tabular}{|c|c|c|c|}
\hline & $\begin{array}{l}\text { Chagas' cardiomyopathy } \\
n=24\end{array}$ & $\begin{array}{l}\text { Idiopathic* cardiomyopathy } \\
\qquad \mathrm{n}=23\end{array}$ & $\begin{array}{l}\text { Ischemic cardiomyopathy } \\
\qquad \mathrm{n}=15\end{array}$ \\
\hline \multicolumn{4}{|l|}{ Demographics } \\
\hline Median age (years) & 37 & 50 & 54 \\
\hline Male & $71 \%$ & $91 \%$ & $100 \%$ \\
\hline \multicolumn{4}{|l|}{ Risk factors } \\
\hline Previous MI & 0 & 0 & $87 \%$ \\
\hline Arterial hypertension & 0 & 0 & $40 \%$ \\
\hline Smoking & $38 \%$ & $56 \%$ & $80 \%$ \\
\hline Hypercholesterolemia & $8 \%$ & $17 \%$ & $27 \%$ \\
\hline Previous stroke or TIA & $4 \%$ & $4 \%$ & $13 \%$ \\
\hline Diabetes & 0 & $17 \%$ & $7 \%$ \\
\hline Alcoholic beverage & $42 \%$ & $30 \%$ & $47 \%$ \\
\hline
\end{tabular}

*includes one patient with congenital cardiomyopathy

Table 2. Neurologic complications after heart transplantation.

\begin{tabular}{|c|c|c|c|c|c|}
\hline Neurologic complication & $\begin{array}{c}\text { Chagas' } \\
n=24\end{array}$ & $\begin{array}{c}\text { Idiopathic } \\
n=22\end{array}$ & $\begin{array}{c}\text { Ischemic } \\
n=15\end{array}$ & $\begin{array}{c}\text { Congenital } \\
n=1\end{array}$ & $\begin{array}{c}\text { Total } \\
n=62\end{array}$ \\
\hline Drug toxicity or metabolic & $4(17 \%)$ & $5(23 \%)$ & $4(27 \%)$ & 0 & 13 \\
\hline Seizures and/or encephalopathy & 3 & 5 & 3 & 0 & 11 \\
\hline Severe headache & 1 & 0 & 0 & 0 & 1 \\
\hline Tremor & 0 & 0 & 1 & 0 & 1 \\
\hline Peripheral neuropathy & $3(12 \%)$ & 0 & $1(7 \%)$ & 0 & 4 \\
\hline Ulnar & 1 & 0 & 0 & 0 & 1 \\
\hline Peroneal & 2 & 0 & 1 & 0 & 3 \\
\hline Spinal cord compression & 0 & 0 & $2(13 \%)$ & 0 & 2 \\
\hline Metastatic prostate cancer & 0 & 0 & 1 & 0 & 1 \\
\hline Epidural spinal abscess & 0 & 0 & 1 & 0 & 1 \\
\hline Total & 7 (29\%) & $5(23 \%)$ & 7 (47\%) & 0 & 19 (31\%) \\
\hline
\end{tabular}

iopathic and 3 ischemic). All of them had normal brain CT or MRI as well as CSF examinations. Severe headache occurred in one Chagas' patient, while one ischemic patient presented with tremor. None of these 13 episodes could be explained by infections or cerebrovascular events and they were thought to be related to documented metabolic changes (in 2 patients) or to drug toxicity (in 11), including cyclosporine (in 8), imipenem (in 2) and steroids (in 1), as suggested by spontaneous improvement and complete recovery after drug taper. Cyclosporine serum levels were within or just above therapeutic range in all patients. Long term antiepileptic drugs were not used and only one patient had persistent attention and memory deficits.

Acute peripheral neuropathy ( 1 ulnar and 3 peroneal) in the immediate postoperative period occurred in four patients ( 3 Chagas' and 1 ischemic). All of them had complete recovery within two months. These events were probably related to compression due to intraoperative positioning.

Spinal cord compression was observed in two ischemic patients, one caused by metastatic prostate cancer with recovery after treatment and one with epidural abscess (S. aureus) evolving to sepsis and death, despite early surgical decompression combined with antibiotics.

Only one patient with neurologic complication died: the patient with spinal epidural abscess complicated with sepsis.

With the exception of the spinal cord compressions ( 29 and 36 months after transplantation in two patients), all the remaining complications occurred within the first two months after transplantation.

Neurologic complications could not be related to demographic features and risk factors for cerebrovas- 
Table 3. Neurologic complications related to demographic features and risk factors for cerebrovascular diseases.

\begin{tabular}{lccc}
\hline & $\begin{array}{c}\text { Complication } \\
\text { present } \\
\mathrm{n}=19\end{array}$ & $\begin{array}{c}\text { Complication } \\
\text { absent } \\
\mathrm{n}=43\end{array}$ & $\mathrm{p}$ \\
\hline Demographics & & & \\
Median age (years) & 46 & 45 & $0.2^{1}$ \\
Male & $89 \%$ & $34 \%$ & 0.43 \\
Risk factors & & & \\
Arterial hypertension & $16 \%$ & $8 \%$ & 0.26 \\
Diabetes & 0 & $13 \%$ & 0.14 \\
Hypercholesterolemia & $21 \%$ & $16 \%$ & 0.36 \\
Smoking & $53 \%$ & $59 \%$ & 0.51 \\
Alcoholic beverage & $37 \%$ & $40 \%$ & 0.53 \\
Previous stroke or TIA & 0 & $11 \%$ & 0.22 \\
Previous Ml & $31 \%$ & $19 \%$ & 0.15 \\
Previous neurologic & & & \\
$\quad$ abnormalities & 0 & $13 \%$ & 0.14 \\
\hline
\end{tabular}

$\mathrm{p}$ Fisher's exact test except where indicated; ${ }^{1}$ Mann-Whitney $\mathrm{U}$ test.

cular diseases, including previous neurologic abnormalities (Table 3).

There are two noteworthy observations in our series: no symptomatic postoperative stroke was observed and none of the 7 Chagas' patients with systemic $T$. cruzi reactivation had CNS involvement.

\section{DISCUSSION}

Heart transplantation has become a definitive therapeutic option for patients with end-stage cardiac failure, with increasing survival rates after recent advances in surgical techniques and immunosuppression. Neurologic complications, however, are still described as a frequent cause of morbidity and mortality in these patients. Since most of the previous studies are based on autopsy findings or retrospective reviews we conducted a prospective observational study to identify the frequency and outcome of neurologic complications after heart transplantation in our university based hospital.

Of 120 candidates examined preoperatively 62 $(52 \%)$ were transplanted in a 6-year study period. Between 1984 and 1993, 380 heart transplantations were performed in our country by 20 institutions, including ours ${ }^{19}$. These numbers confirm that despite the efforts of educational programs for the population, the activity of transplantation programs in Brazil, as in many other countries, is still severely limited by the availability of donor organs.

Drug related neurotoxicity was the most common neurologic complication in our series (21\%). Eleven of our patients presented with seizures, sometimes accompanied by transient encephalopathy, one patient presented with headache and another patient with tremor. Seizures were seldom recurrent and no patient received long-term antiepileptic drugs, as described before ${ }^{20,21}$. Cyclosporine-associated neurotoxicity, is a well known complication in liver, kidney, bone marrow and heart transplantations. The spectrum of clinical presentation includes seizures, altered mental status with confusion, hallucinations, tremor, headache, encephalopathy, cortical blindness and coma, sometimes in combination ${ }^{20,22,23}$. The frequency of these complications ranges from 10 to $40 \%$ with a peak in the early postoperative period $20,22,23$ and most of the patients present reversible and recurrent symptoms or signs related to drug discontinuation and reintroduction. Symptoms may occur in the absence of documented high cyclosporine levels $^{24}$, as observed in our patients and the diagnosis is usually one of exclusion ${ }^{22}$, often requiring normal CT scan or MRI and lumbar puncture to rule out infection or cerebrovascular events. The concomitant use of other drugs such as steroids and imipenem or the presence of metabolic changes, as observed in 5 of our patients, can mimic cyclosporine-associated neurotoxicity symptoms.

Postoperative acute peripheral neuropathy occurred in $6 \%$ of our patients, probably related to intraoperative positioning, and with a benign prognosis. The frequency of this finding in heart transplantation is thought to be similar to that described after open-heart surgery ${ }^{21,25,26}$. We observed a trend to higher frequency of peripheral neuropathy in Chagas' patients. Nascimento and coworkers ${ }^{27}$ described a patient with chronic inflammatory neuropathy probably related to Chagas' disease, and postulated an immune delayed hypersensitivity mechanism to explain this finding. One might suppose that subclinical preexistent neuropathy may have predisposed Chagas' patients to the acute neuropathy observed. However, the two diabetic patients with mild signs of peripheral neuropathy in the preoperative examination did not present new symptoms or worsening of prior symptoms suggestive of acute peripheral nerve lesions in the postoperative period.

Except for a possible susceptibility to peripheral neuropathy, neurologic complications detected in the present study were similar in Chagas' and non-Chagas' patients, and could not be specifically related to Chagas' disease, as described before ${ }^{28}$. Chagas' patients have not been included in the previous se- 
ries that addressed the neurologic complications of transplantation ${ }^{1-10,14}$ and one might suppose that they could be at a higher risk of complications due to immunosuppression. Reactivation of Chagas' disease with CNS involvement has been described in kidney transplantation, leukemia and HIV patients ${ }^{29-35}$. Seven of our patients presented cutaneous and myocardial reactivation but none of them had neurologic symptoms. Early prednisone withdrawn in Chagas' patients may contribute to a reduction of systemic reactivation observed after heart transplantation as described before ${ }^{36,37}$. However, the absence of CNS involvement in our seven patients with systemic reactivation deserves further elucidation.

Spinal epidural empyema occurred in one ischemic patient. Although described in renal ${ }^{38,39}$ and li$v^{2}{ }^{40}$ transplant recipients, this complication is rare and as far as we know has not been previously described in heart transplant recipients.

The absence of symptomatic postoperative strokes in our patients is intriguing. Although most recent cerebral infarcts are symptomatic, some silent perioperative events may have been underestimated in our patients due to methodological limitations. However, infarctions observed in previous autopsy and clinical retrospective series may also be overestimated considering that they may represent silent preoperative events. Moreover, some series included 50 to $67 \%$ of patients with ischemic cardiomyopathy $^{5,8,14}$, that may present previous atherosclerotic disease; one can speculate that cerebrovascular disease may antedate heart transplantation in those patients, as suggested by Adair and coworkers ${ }^{14}$. Recently, Jarquin-Valdivia and coworkers ${ }^{9}$ reported an increase in ischemic stroke in patients with dilated cardiomyopathy among their series, which they attribute to heart and aortic manipulation. However, these risk factors are expected to be similar or even higher in patients with ischemic cardiomyopathy, and the authors comment that this finding may have to be interpreted with caution. A future prospective study including routine pre- and postoperative evaluation with new MRI techniques may help to elucidate this question.

Apart from the sample size that might explain at least part of the negative results in the statistical analysis, the present study may have underestimated the neurologic complications observed due to methodological limitations: although all patients were examined by the same neurologist before transplantation, neurologic events were determined by the transplant team in the postoperative period. There- fore only the cases referred for consultation were examined, which could have resulted in low sensitivity of detection in patients with minor deficits. The transplant team, however, was the same throughout the study period and a very close relationship between the members of the team ensured prompt evaluation of any patient with neurologic symptoms.

In conclusion, neurologic complications occurred in $31 \%$ of our patients. Although frequent, those complications were seldom related to persistent neurologic disability or death. Most of the complications resulted from immunosuppression (predominantly cyclosporine toxicity); however, CNS infection was rare, even in patients with Chagas' disease who could be potentially at a higher risk of $T$. cruzi reactivation. The absence of strokes in our series may be related to the lower frequency of ischemic cardiomyopathy. This observation may contribute to the hypothesis that strokes are primarily associated with previous atherosclerotic cardiovascular disease rather than with the surgery itself.

\section{REFERENCES}

1. Schober R, Herman MM. Neuropathology of cardiac transplantation: survey of 31 cases. Lancet 1973;1:962-967.

2. Montero CG, Martinez AJ. Neuropathology of heart transplantation: 23 cases. Neurology 1986;36:1149-1154.

3. Ang LC, Gillett JM, Kaufmann JCE. Neuropathology of heart transplantation. Can J Neurol Sci 1989;16:291-298.

4. Prayson RA, Estes ML. The neuropatology of cardiac allograft transplantation: an autopsy series of 18 patients. Arch Pathol Lab Med 1995;119:59-163.

5. Hotson JR, Pedley TA. The neurological complications of cardiac transplantation. Brain 1976; 99:673-694.

6. Britt RH, Enzmann DR, Remington JS. Intracranial infection in cardiac transplant recipients. Ann Neurol 1981;9:107-119.

7. Hall WA, Martinez AJ, Dummer JS, et al. Central nervous system infections in heart and heart-lung transplant recipients. Arch Neurol 1989;46:173-177.

8. Andrews BT, Hershon JJ, Calanchini P, Avery GJ 2nd, Hill JD. Neurologic complications of cardiac transplantation. West J Med 1990;153:146-148.

9. Jarquin-Valdivia AA, Wijdicks EFM, McGregor C. Neurologic complications following heart transplantation in the modern era: decreased incidence, but postoperative stroke remains prevalent. Transplant Proc 1999;31:2161-2162.

10. Guillon B, Wiertlewski S, Trochu J-N, et al. Les complications cérébrovasculaires tardives de la transplantation cardiaque. Rev Neurol (Paris) 2000;156:264-269.

11. Martin AB, Bricker JT, Fishman M, et al. Neurologic complications of heart transplantation in children. J Heart Lung Transplant 1992;11:933-942.

12. Lynch BJ, Glauser TA, Canter C, Spray T. Neurologic complications of pediatric heart transplantation. Arch Pediatr Adolesc Med 1994;148:973-979.

13. Rosenfeld V, Dubrovsky T, Geith T, Pearse L. Neurologic complications in pediatric heart transplantation. Neurology 1998;50(Suppl 4):A243.

14. Adair JC, Call GK, O'Connell JB, Baringer JR. Cerebrovascular syndromes following cardiac transplantation. Neurology 1992;42:819-823.

15. Moncayo A. Progress towards the elimination of transmission of Chagas disease in Latin America. World Health Stat Q 1997;50:195-198.

16. Billingham ME, Cary NRB, Hammond ME, et al. A working formulation for the standardization of nomenclature in the diagnosis of heart and lung rejection: Heart Rejection Study Group. The International Society for Heart Transplantation. J Heart Transplant 1990;9:587-593.

17. Gallerano RH, Marr JJ, Sosa RR. Therapeutic efficacy of allopurinol in patients with chronic Chagas' disease. Am J Trop Med Hyg 1990; 43:159-166. 
18. Almeida DR, Carvalho AC, Branco JN, et al. Chagas' disease reactivation after heart transplantation: efficacy of allopurinol treatment. J Heart Lung Transplantation 1996;15:988-992.

19. Stolf NA. Human heart transplantation in Brazil. Arq Bras Cardiol. 1994;63:247-250.

20. Patchell RA. Neurological complications of organ transplantation. Ann Neurol 1994;36:688-703.

21. Sila CA. Spectrum of neurologic events following cardiac transplantation. Stroke 1989;20:1586-1589.

22. Miller LW. Cyclosporine-associated neurotoxicity: the need for a better guide for immunosuppressive therapy. Circulation 1996;94:1209-1211.

23. Gijtenbeek JM, Van den Bent MJ, Vecht CJ. Cyclosporine neurotoxicity: a review. J Neurol 1999;246:339-346.

24. Baulac M, Smadja D, Cabrol A, Cabrol C, LaPlane D. Cyclosporin and convulsions after cardiac transplantation. Rev Neurol (Paris) 1989;145:393-397.

25. Lederman RJ, Breuer AC, Hanson MR, et al. Peripheral nervous system complications of coronary artery bypass graft surgery. Ann Neurol 1982;12:297-301.

26. Hotson JR, Enzmann DR. Neurologic complications of cardiac transplantation. Neurol Clin 1988;6:349-365.

27. Nascimento OJ, Freitas MR, Chimelli L. Axonal polyneuropathy in Chagas' disease. Rev Neurol (Paris) 1991;147:679-681.

28. Malheiros SMF, Gabbai AA, Brucki SMD, et al. Neurologic outcome after heart transplantation in Chagas' disease: preliminary results. Acta Neurol Scand 1997;96:252-255.

29. Pizzi T, de Croizet VA, Smok G, Diaz M. Enfermedad de Chagas en un paciente con transplante renal y tratamiento inmunosupresor. Rev Med Chile 1982;110:1207-1211.

30. Corona S, Amanales C, Avaria MA, et al. Granuloma chagasico del cerebro en un paciente con leucemia linfoblastica. Rev Med Chile 1988;116:676-680.
31. Del Castillo M, Mendoza G, Oviedo J, Bianco RPP, Anselmo AE, Silva M. AIDS and Chagas' disease with central nervous system tumor-like lesion. Am J Med 1990;88:693-694.

32. Ferreira MS, Nishioka SA, Rocha A, et al. Acute fatal Trypanosoma cruzi meningoencephalitis in a human immunodeficiency virus-positive hemophiliac patient. Am J Trop Med Hyg 1991;45:723-727.

33. Gluckstein D, Cifierri F, Ruskin J. Chagas' disease: another cause of cerebral mass in the acquired immunodeficiency syndrome. Am J Med 1992;92:429-432.

34. Jardim E, Takayanagui OM. Chagasic meningoencephalitis with detection of Trypanosoma cruzi in the cerebrospinal fluid of a immunodepressed patient. J Trop Med Hyg 1994;97:367-370.

35. Pagano MA, Segura MJ, Di Lorenzo GA, et al. Cerebral tumor-like American trypanosomiasis in acquired immunodeficiency syndrome. Ann Neurol 1999;45:403-406.

36. Bestetti RB, Castilho OT, Teno LAC, Freitas OC. Absence of Trypanosoma cruzi infection reactivation in Chagas'heart transplant. Cardiovasc Pathol 1994;3:257-259.

37. Carvalho VB, Sousa EFL, Vila JHA, et al. Heart transplantation in Chagas' disease. 10 years after the initial experience. Circulation 1996;94:1815-1817.

38. Ingwer I, McLeish KR, Tight RR, White AC. Aspergillus fumigatus epidural abscess in a renal transplant recipient. Arch Intern Med 1978;138:153-154.

39. Delmas Y, Merville P, Dousset V, Dervau-Durieux L, Morel D, Potaux L. A renal transplant recipient with acute paraparesis due to an Aspergillus epidural abscess. Nephrol Dial Transplant 1997;12:2185-2187.

40. Wszolek ZK, McCashland TM, Witte RJ, Brandenberg GA, Steg RE. Spinal epidural abscess in a liver transplant recipient. Transplant Proc 1996;28:2978-2979. 